\title{
Nitrite inhibition of microalgae induced by the competition between microalgae
}

and nitrifying bacteria

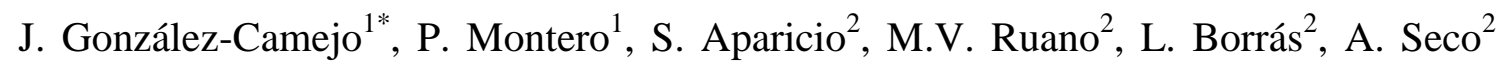
and R. Barat ${ }^{1}$.

${ }^{1}$ CALAGUA - Unidad Mixta UV-UPV, Institut Universitari d'Investigació d'Enginyeria de l'Aigua i Medi Ambient - IIAMA, Universitat Politècnica de València, Camí de Vera s/n, 46022 Valencia, Spain.

${ }^{2}$ CALAGUA - Unidad Mixta UV-UPV, Departament d'Enginyeria Química, Universitat de València, Avinguda de la Universitat s/n, 46100 Burjassot, Valencia, Spain.

*Corresponding author

Email address: jogonca4@upv.es (J. González-Camejo)

\section{Abstract}

Outdoor microalgae cultivation systems treating anaerobic membrane bioreactor (AnMBR) effluents usually present ammonium oxidising bacteria (AOB) competition with microalgae for ammonium uptake, which can cause nitrite accumulation. In literature, nitrite effects over microalgae have shown controversial results. The present study evaluates the nitrite inhibition role in a microalgae-nitrifying bacteria culture. For this purpose, pilot- and lab-scale assays were carried out. During the continuous outdoor operation of the membrane photobioreactor (MPBR) plant, biomass retention time (BRT) of $2 \mathrm{~d}$ favoured AOB activity, which caused nitrite accumulation. This nitrite was confirmed to inhibit microalgae performance. Specifically, continuous 5-d lab-scale assays showed a reduction in the nitrogen recovery efficiency by 32,42 and $80 \%$ when nitrite concentration in the culture accounted for 5,10 and $20 \mathrm{mg} \mathrm{N} \cdot \mathrm{L}^{-1}$, respectively. On the contrary, short 30-min exposure to nitrite showed no significant differences in 
the photosynthetic activity of microalgae under nitrite concentrations of $0,5,10$ and 20 mg N. $\mathrm{L}^{-1}$. On the other hand, when the MPBR plant was operated at 2.5-d BRT, the nitrite concentration was reduced to negligible values due to increasing activity of microalgae and nitrite oxidising bacteria (NOB). This allowed obtaining maximum MPBR performance; i.e. nitrogen recovery rate (NRR) and biomass productivity of 19.7 $\pm 3.3 \mathrm{mg} \mathrm{N} \cdot \mathrm{L}^{-1} \cdot \mathrm{d}^{-1}$ and $139 \pm 35 \mathrm{mg} \mathrm{VSS} \cdot \mathrm{L}^{-1} \cdot \mathrm{d}^{-1}$, respectively; while nitrification rate (NOxR) reached the lowest value $\left(13.5 \pm 3.4 \mathrm{mg} \mathrm{N} \cdot \mathrm{L}^{-1} \cdot \mathrm{d}^{-1}\right)$. Long BRT of $4.5 \mathrm{~d}$ favoured NOB growth, avoiding nitrite inhibition. However, it implied a decrease in microalgae growth and the accumulation of nitrate in the MPBR effluent. Hence, it seems that optimum BRT has to be within the range $2-4.5 \mathrm{~d}$ in order to favour microalgae growth with respect to AOB and NOB.

\section{Introduction}

The need to look for new sustainable resources and technologies has raised the interest of the scientific community in microalgae cultivation for wastewater treatment. Microalgae need large amounts of nutrients to grow which can be recovered from wastewater streams, implying a simultaneous removal of nitrogen and phosphorus from wastewater (Santos and Pires, 2018). High nutrient-loaded discharges to the environment are thus avoided, preventing the eutrophication of the natural water bodies (Eze et al., 2018). In addition, carbon dioxide is biofixed to obtain microalgae biomass (Bilad et al., 2018) that can be used to produce biofuels, biopolymers, biofertilisers, feeding and pharmaceuticals products, etc. (Santos and Pires, 2018).

Anaerobic membrane bioreactor (AnMBR) effluents have appeared to be ideal medium to enhance microalgae growth since they contain all the macro and micronutrients needed for microalgae growth and low amounts of solids and organic matter (Ruiz- 
Martínez et al., 2012). However, in large-scale outdoor microalgae cultivation systems, microalgae often coexist with other microorganisms that can act as competitors (Gonçalves et al., 2017; González-Camejo et al., 2019a). Since AnMBR effluents usually present high ammonium loads and low organic matter concentration (Seco et al., 2018), the competition between microalgae and ammonium oxidising bacteria (AOB) for ammonium uptake is likely to occur (Molinuevo-Salces et al., 2010). AOB are autotrophic organisms that use ammonium as a source of electrons and oxidises it to nitrite as long as they are not oxygen limited (Akizuki et al., 2019a). This nitrite can be used by nitrite oxidising bacteria (NOB) to carry out the second step of nitrification, oxidising it to nitrate (Winkler and Straka, 2019).

Depending on ambient and operating conditions, nitrifying bacteria activity can boost the nitrite accumulation in the culture (Marazzi et al., 2019). For instance, AOB growth is sharply increased with temperature (González-Camejo et al., 2019a; Jiménez, 2010), which implies that sudden temperature increases can make AOB to rapidly proliferate. In addition, excessive solar radiation inhibits nitrifying bacteria activity (Akizuki et al., 2019b). In this respect, NOB is more affected by light than AOB, which can make nitrite accumulate under light intensities higher than $225 \mu \mathrm{mol} \cdot \mathrm{m}^{-2} \cdot \mathrm{s}^{-1}$ (Vergara et al., 2016). Furthermore, if oxygen is limiting, nitrite concentration can increase due to the faster oxygen consumption of AOB in comparison to NOB (Kwon et al., 2019). Another key factor related to nitrite accumulation is BRT since it has significant influence on microalgae-AOB competition (Rada-Ariza et al., 2019). However, scarce studies have focused on the effect of hydraulic retention time (HRT) and BRT on nitrite accumulation in outdoor microalgae-based wastewater treatment systems.

It should be highlighted that in spite of nitrite can act as nitrogen source for microalgae growth (Gupta et al., 2019), its accumulation in a microalgae culture is not convenient 
since nitrite ion can negatively affect microalgae (Abe et al., 2002). According to Sijbesma et al. (1996), nitrite ion increases the proton permeability of cell membranes, inhibiting the adenosine triphosphate (ATP) synthesis and stimulating its hydrolysis. In addition, Almeida et al. (1995) reported that $\mathrm{NO}_{2}$ could be responsible for a decreasing efficiency of respiratory-chain-linked energy conservation since nitrite induced proton permeability, which counteracted the proton pumping effect of the enzyme ATP-ase. Nitrite has also been reported to inhibit photosynthetic electron transport (Chen et al., 2009). It must be considered that the sensitivity of microalgae to nitrite is speciesspecific and results reported in the literature are controversial. By way of example, Yang et al. (2004) observed a decay in the growth of Botryococcus braunii at nitrite concentrations of $70 \mathrm{mg} \mathrm{N} \cdot \mathrm{L}^{-1}$. Furthermore, Admiraal (1977) observed high reduction in the growth of ten diatom species (marine microalgae) under nitrite concentration of $10 \mathrm{mg} \mathrm{N} \cdot \mathrm{L}^{-1}$. On the other hand, Abe et al. (2002) did not observed any reduction in the growth of aerial microalgae Trentepohlia aurea at concentrations under $141 \mathrm{mg} \mathrm{N} \cdot \mathrm{L}^{-1}$. To the best of our knowledge, the nitrite effect on green microalgae Chlorella has not been evaluated previously.

It must be also bear in mind that nitrite ion is related to nitrous acid $\left(\mathrm{HNO}_{2}\right)$ through acid-base equilibrium. This relationship is $\mathrm{pH}$-dependent. High nitrite concentrations can thus modify intracellular pH significantly, affecting microalgae activity (Chen et al., 2009). In addition, $\mathrm{HNO}_{2}$ has been reported to inhibit microorganisms such as AOB and NOB (Blackburne et al., 2007; Jiménez, 2010). Hence, the possible effects of $\mathrm{HNO}_{2}$ on microalgae should also be considered. To implement microalgae cultivation technology, it thus seems necessary to evaluate the effect of nitrite concentration and the factors related to its accumulation on an outdoor microalgae-nitrifying bacteria culture used to treat AnMBR effluent, where nitrite concentrations are expected to be in the range of 0- 
$15 \mathrm{mg} \mathrm{N} \cdot \mathrm{L}^{-1}$ (González-Camejo et al., 2018). This study has two goals: i) to provide a better understanding of the microalgae-AOB competition in the outdoor treatment of AnMBR effluents, focusing on maximising nitrogen recovery by microalgae, therefore decreasing the effluent nitrogen concentration; and ii) to evaluate the microalgae inhibition by the presence of nitrite under controlled lab-scale conditions.

\section{Material and methods}

\subsection{Microalgae and wastewater}

The microalgae-nitrifying bacteria culture was dominated by Chlorella genera (> 99\% of total eukaryotic cells (TEC)), although cyanobacteria and heterotrophic bacteria were also present in negligible concentrations. It must be noted that biomass concentration of nitrifying bacteria was also negligible in comparison to microalgae according to microscopic observations.

The wastewater to be treated consisted of the nutrient-rich effluent from an AnMBR plant that was fed by the primary settler effluent of the Carraixet WWTP $\left(39^{\circ} 30^{\prime} 04.0^{\prime \prime} \mathrm{N} 0^{\circ} 20^{\prime} 00.1^{\prime \prime} \mathrm{W}\right.$, Valencia, Spain). This AnMBR plant is described in Seco et al. (2018). The average characteristics of this substrate were a nitrogen concentration of $48.8 \pm 8.7 \mathrm{mg} \mathrm{N} \cdot \mathrm{L}^{-1}$ (mainly ammonium; i.e. > 95\% of nitrogen), a phosphorus concentration of $4.4 \pm 1.5 \mathrm{mg} \mathrm{P} \cdot \mathrm{L}^{-1}$ and a chemical oxygen demand (COD) concentration of $63 \pm 32 \mathrm{mg} \mathrm{COD} \cdot \mathrm{L}^{-1}$. Volatile suspended solids concentration was negligible. 


\subsection{Experimental set up}

Two different groups of experiments were tested: i) large-scale experiments operating an outdoor membrane photobioreactor (MPBR) plant; and ii) lab-scale assays to confirm the nitrite inhibition of microalgae.

\subsubsection{MPBR pilot plant}

The MPBR plant was located in the Carraixet WWTP (Valencia, Spain). It was operated under outdoor conditions with variable light and temperature and consisted of two flatplate photobioreactors (PBRs) connected to a membrane tank (MT). Each PBR had a working volume of $230 \mathrm{~L}$ with dimensions of 1.15-m high, 2-m wide and 0.10-m deep. They were continuously stirred by $\mathrm{CO}_{2}$-enriched air to ensure the culture homogenisation and prevent wall fouling. $\mathrm{CO}_{2}$ was injected into the aeration system to maintain $\mathrm{pH}$ values at $7.5 \pm 0.8$. This also ensured carbon-replete conditions and avoided undesirable abiotic processes such as ammonia volatilisation and phosphorus precipitation (Whitton et al., 2016). Moreover, it maintained $\mathrm{HNO}_{2}$ concentration at negligible values since under this $\mathrm{pH}$, the $\mathrm{NO}_{2}{ }^{-} / \mathrm{HNO}_{2}$ equilibrium favours nitrite ion (see Eq. 5).

Both PBRs had an additional artificial white light source consisted of twelve LED lamps (Unique Led IP65 WS-TP4S-40W-ME) that were installed at the back of each PBR offering a continuous light irradiance of $300 \mu \mathrm{mol} \cdot \mathrm{m}^{-2} \cdot \mathrm{s}^{-1}$ at the PBR surface.

The MT had a total working volume of $14 \mathrm{~L}$ and a filtration area of $3.4 \mathrm{~m}^{2}$. It consisted of one hollow-fibre ultrafiltration membrane bundle extracted from an industrial-scale membrane unit (PURON ${ }^{\circledR}$ Koch Membrane Systems (PUR-PSH31), $0.03 \mu \mathrm{m}$ pores). Air was injected into the bottom of the MT to reduce membrane fouling by membrane scouring. 
The continuous operation of the MPBR plant is extensively described in GonzálezCamejo et al. (2019b).

\subsubsection{Outdoor experimental periods}

Two different groups of periods were tested to evaluate the accumulation of nitrite in the microalgae-nitrifying bacteria culture. In the dilution rate period (DR-Period) the effect of a punctual increase in the dilution rate of the culture was assessed. To this aim, the dilution rate of the MPBR plant increased from $0.3 \mathrm{~d}^{-1}$ to $0.5 \mathrm{~d}^{-1}$ on day 31 , reestablishing it to $0.3 \mathrm{~d}^{-1}$ after that punctual dilution.

To analyse the effect of BRT on the nitrite production, 3 Periods were selected; i.e., Period BRT-2; BRT-2.5 and BRT-4.5 which corresponded to BRTs 2, 2.5 and $4.5 \mathrm{~d}$, respectively. Average solar photosynthetically active radiation (PAR), temperature and BRT-HRT conditions of each period are depicted in Table 1.

Table 1. Experimental conditions for the continuous operation of the MPBR plant (mean \pm standard deviation).

\begin{tabular}{cccccc}
\hline Period & $\begin{array}{c}\text { Days of } \\
\text { operation }\end{array}$ & $\begin{array}{c}\text { Solar PAR } \\
\left(\boldsymbol{\mu m o l} \cdot \mathbf{m}^{-2} \cdot \mathbf{s}^{-\mathbf{1}}\right)\end{array}$ & $\begin{array}{c}\text { Temperature } \\
\left({ }^{\mathbf{0}} \mathbf{C}\right)\end{array}$ & $\begin{array}{c}\text { BRT } \\
(\mathbf{d})\end{array}$ & $\begin{array}{c}\text { HRT } \\
(\mathbf{d})\end{array}$ \\
\hline DR & 45 & $234 \pm 33$ & $24.7 \pm 1.2$ & 3 & 1 \\
\hline BRT-2 & 24 & $277 \pm 104$ & $18.6 \pm 1.9$ & 2 & 1.25 \\
BRT-2.5 & 37 & $284 \pm 138$ & $16.9 \pm 2.2$ & 2.5 & 1.25 \\
BRT-4.5 & 37 & $277 \pm 101$ & $18.8 \pm 2.4$ & 4.5 & 1.25 \\
\hline
\end{tabular}

Each group of periods; i.e., DR-periods and BRT-periods was preceded by a start-up phase (González-Camejo et al., 2019b) which was not considered in the results. 
However, the transition between periods of the same group was made without a start-up phase.

\subsubsection{Lab-scale assays}

To confirm the microalgae inhibition by nitrite, two groups of highly controlled labscale assays were carried out: i) short-term exposure assays which lasted $30 \mathrm{~min}$; and ii) continuous exposure of microalgae to nitrite for 5 days.

\subsubsection{Short-term exposure}

Short-term exposure assays consisted of respirometric tests that were carried out (in duplicate) to obtain the oxygen production rate (OPR) of microalgae cultures with nitrite concentrations of $0,5,10$ and $20 \mathrm{mg} \mathrm{N} \cdot \mathrm{L}^{-1}$, respectively. These concentrations were achieved by adding the corresponding amount of a standard dilution of $1000 \mathrm{mg}$ $\mathrm{NO}_{2} \cdot \mathrm{L}^{-1}$ to the diluted microalgae samples which consisted of $200 \mathrm{~mL}$ of microalgae culture taken from the MPBR plant (see section 2.2.1) and $200 \mathrm{~mL}$ of AnMBR effluent (section 2.1). All the respirometric tests were carried out with the same mix of microalgae and substrate samples, only differing in the nitrite concentration of the culture. In this respect, the biomass concentration of the mixed samples accounted for $225 \pm 22 \mathrm{mg}$ VSS $\cdot \mathrm{L}^{-1}$. Differences due to shadow effect were therefore not considered (Rossi et al., 2018). Moreover, the mixed samples presented ammonium and phosphate concentrations of $21.1 \pm 2.5 \mathrm{mg} \mathrm{N} \cdot \mathrm{L}^{-1}$ and $2.8 \pm 0.8 \mathrm{mg} \mathrm{P} \cdot \mathrm{L}^{-1}$, respectively. Nutrient limitation was thus avoided (González- Camejo et al., 2019b). $10 \mathrm{mg} \cdot \mathrm{L}^{-1}$ of allylthiourea (ATU) were added to each respirometric sample in order to prevent any possible negative effect of AOB over microalgae (González-Camejo et al., 2019a). 
Consequently, these tests only assessed the effect of nitrite concentration on microalgae growth.

The set up consisted of a cylindrical closed PBR (400 mL of working volume) which was placed inside a thermostatic chamber at $25^{\circ} \mathrm{C}$. The PBR was lit by four cool-white LED lamps (T8 LED-Tube $9 \mathrm{w}$ ) to supply a light intensity of $125 \mu \mathrm{mol} \cdot \mathrm{m}^{-2} \cdot \mathrm{s}^{-1}$ on the PBR surface. An oxygen probe (WTW CellOx 330i) monitored the dissolved oxygen (DO) concentration of the culture during the 30 minutes that each test lasted. Data were collected every $30 \mathrm{~s}$. The culture was stirred at $200 \mathrm{rpm}$ to ensure appropriate homogenisation and prevent microalgae sedimentation. An on-off valve was opened to add pure $\mathrm{CO}_{2}$ when $\mathrm{pH}$ exceeded a set-point value (7.5) to avoid carbon limitation and control $\mathrm{pH}$, which was maintained at $7.4 \pm 0.5$.

\subsubsection{Continuous lab-scale operation}

For the continuous lab-scale operation, two 8-L vertical reactors (R-A and R-B) were used. Three different assays $\left(\mathrm{L}_{5}, \mathrm{~L}_{10}\right.$ and $\left.\mathrm{L}_{20}\right)$ were carried out to evaluate the same nitrite concentrations that were used in the respirometries; i.e. 5,10 and $20 \mathrm{mg} \mathrm{N} \cdot \mathrm{L}^{-1}$. Both reactors were filled with $33 \%$ of substrate (i.e. AnMBR effluent) and $67 \%$ of the microalgae culture from the MPBR plant (see section 2.1). Hence, R-A and R-B started with the same nutrient conditions in each continuous lab-scale assay, except for nitrite, which was added to R-B by using a standard dilution of $1000 \mathrm{mg} \mathrm{NO} \cdot \mathrm{L}^{-1}$ in concentrations of 5,10 and $20 \mathrm{mg} \mathrm{N} \cdot \mathrm{L}^{-1}$ for lab-scale assays $\mathrm{L}_{5}, \mathrm{~L}_{10}$ and $\mathrm{L}_{20}$, respectively. As different assays used microalgae cultures and substrate with different characteristics (Table 2), each lab-scale assay started at different nutrient concentrations. For this reason, R-A (in which no nitrite was added) was always used as control in each lab-scale test. 
Table 2. Characteristics of the microalgae culture and substrate in the continuous labscale assays.

\begin{tabular}{ccccc|cccc} 
& \multicolumn{4}{c|}{ Substrate $\left(\mathbf{m g} \cdot \mathbf{L}^{-\mathbf{1}}\right)$} & \multicolumn{4}{c}{ Culture $\left(\mathbf{m g} \cdot \mathbf{L}^{-\mathbf{1}}\right)$} \\
\hline Assay & $\mathbf{N H}_{\mathbf{4}}$ & $\mathbf{N}_{\mathbf{s}}$ & $\mathbf{P}$ & VSS & $\mathbf{N H}_{\mathbf{4}}$ & $\mathbf{N}_{\mathbf{s}}$ & $\mathbf{P}$ & VSS \\
\hline $\mathrm{L}_{5}$ & 62.4 & 64.6 & 7.3 & L LOD* $^{*}$ & 33.4 & 41.7 & 4.1 & 857 \\
$\mathrm{~L}_{10}$ & 48.5 & 51.2 & 3.0 & L LOD* $^{*}$ & 11.5 & 14.1 & 0.0 & 590 \\
$\mathrm{~L}_{20}$ & 52.5 & 54.3 & 4.0 & L LOD* $^{*}$ & 11.9 & 50.6 & 0.0 & 423
\end{tabular}

$\mathrm{NH}_{4}$ : ammonium; $\mathrm{NO}_{2}$ : nitrite; $\mathrm{Ns:}$ total soluble nitrogen measured as the sum of $\mathrm{NH}_{4}, \mathrm{NO}_{2}$ and nitrate $\left(\mathrm{NO}_{3}\right)$; P: phosphorus; VSS: volatile suspended solids; LOD: Limit of detection

Similar to respirometries (section 2.2.2.1), an ATU dose was added to both reactors to avoid AOB activity (González-Camejo et al., 2019a). R-A and R-B were placed in a thermostatic chamber maintaining the culture temperature at around $25^{\circ} \mathrm{C}$. They were air-stirred at $0.6 \mathrm{vvm}$ to homogenise the culture and avoid biofilm formation and microalgae sedimentation. To control the culture $\mathrm{pH}, \mathrm{CO}_{2}$ was injected to maintain $\mathrm{pH}$ approximately constant $(7.3 \pm 0.2)$. Four cool-white LED lamps (T8 LED-Tube 9 w) were placed vertically around each reactor to supply a light PAR of $125 \mu \mathrm{mol} \cdot \mathrm{m}^{-2} \mathrm{~s}^{-1}$ at the reactor's surface.

Reactors were operated in semi-continuous mode, maintaining 3-d HRT (with no biomass retention; i.e. BRT also accounted for 3 d) during 5-d experiments. Similarly to MPBR experiments, the performance of both reactors was compared in terms of nitrogen and phosphorus recovery rates and biomass productivity.

\subsection{Sampling and analytical methods}

Daily grab samples of R-A and R-B were measured in duplicate for the continuous labscale assays. With respect to the continuous operation of the MPBR plant, samples from the AnMBR effluent (MPBR influent) and from the MPBR plant effluent were collected three times a week and measured in duplicate. 
Ammonium $\left(\mathrm{NH}_{4}\right)$, nitrite $\left(\mathrm{NO}_{2}\right)$, nitrate $\left(\mathrm{NO}_{3}\right)$ and phosphorus $(\mathrm{P})$ were measured using an automatic analyser (Smartchem 200, WestcoScientific Instruments, Westco) according to Standard Methods (APHA, 2005): 4500-NH3-G, 4500-NO2-B, 4500-NO3$\mathrm{H}$ and 4500-P-F, respectively. Total soluble nitrogen $\left(\mathrm{N}_{\mathrm{S}}\right)$ was obtained as the sum of the three measured nitrogen species; i.e. $\mathrm{NH}_{4}, \mathrm{NO}_{2}$ and $\mathrm{NO}_{3}$. The volatile suspended solids (VSS) concentration was also measured according to method 2540 E of Standard Methods (APHA, 2005).

The chemical oxygen demand was performed according to Standard Methods (APHA, 2005) 5220-COD-C.

\subsection{Calculations}

The net OPR ( $\left.\mathrm{mg} \mathrm{O}_{2} \cdot \mathrm{L}^{-1} \cdot \mathrm{h}^{-1}\right)$ was calculated by [Eq. 1]:

$\frac{d D O}{d t}=k_{L} a \cdot\left(D O_{S A T}-D O\right)+O P R$

[Eq. 1]

where $\mathrm{dDO} / \mathrm{dt}$ is the variation of the oxygen concentration over time $\left(\mathrm{mg} \mathrm{O} \mathrm{O}_{2} \cdot \mathrm{L}^{-1} \cdot \mathrm{h}^{-1}\right)$, $\mathrm{k}_{\mathrm{L}} \mathrm{a}$ is the oxygen mass transfer coefficient $\left(\mathrm{h}^{-1}\right)$, DO $\mathrm{SAT}_{\mathrm{SA}}$ is the oxygen saturation concentration at the culture temperature $\left(\mathrm{mg} \mathrm{O} \mathrm{O}_{2} \cdot \mathrm{L}^{-1}\right)$ and $\mathrm{DO}$ is the oxygen concentration in the culture $\left(\mathrm{mg} \mathrm{O}_{2} \cdot \mathrm{L}^{-1}\right)$.

$\mathrm{k}_{\mathrm{L}} \mathrm{a}$ was evaluated by doing respirometric tests with clean water as medium (in triplicate). A mean value of $0.30 \mathrm{~h}^{-1}$ was obtained by applying Eq. 1 considering null OPR. The minimum square error criterion was used to optimally fit OPR in Eq. 1 (Rossi et al., 2018).

Biomass productivity $\left(\mathrm{mg} \mathrm{VSS} \cdot \mathrm{L}^{-1} \cdot \mathrm{d}^{-1}\right)$ and nitrogen recovery rate $(\mathrm{NRR})\left(\mathrm{mg} \mathrm{N} \cdot \mathrm{L}^{-1} \cdot \mathrm{d}^{-}\right.$ ${ }^{1}$ ) were calculated as reported by González-Camejo et al. (2018).

The nitrification rate $(\mathrm{NOxR})\left(\mathrm{mg} \mathrm{N} \cdot \mathrm{L}^{-1} \cdot \mathrm{d}^{-1}\right)$ was obtained by [Eq. 2]:

$$
N O x R=\frac{F \cdot\left(N O x_{e}-N O x_{i}\right)}{V_{M P B R}} \quad[\text { Eq. 2] }
$$


where $\mathrm{F}$ is the treatment flow rate $\left(\mathrm{m}^{3} \cdot \mathrm{d}^{-1}\right) ; \mathrm{NOx}_{\mathrm{e}}$ is the concentration of nitrite plus nitrate of the effluent $\left(\mathrm{mg} \mathrm{N} \cdot \mathrm{L}^{-1}\right)$; $\mathrm{NOx}_{\mathrm{i}}$ is the concentration of nitrite plus nitrate of the influent $\left(\mathrm{mg} \mathrm{N} \cdot \mathrm{L}^{-1}\right)$; and $\mathrm{V}_{\mathrm{MPBR}}$ is the volume of the culture in the MPBR plant $\left(\mathrm{m}^{3}\right)$.

The concentration of free ammonia $\left(\mathrm{NH}_{3}\right)\left(\mathrm{mg} \mathrm{N} \cdot \mathrm{L}^{-1}\right)$ in the system was obtained from the Anthonisen equation [Eq. 3] (Anthonisen et al., 1976). As a conservative calculation, all the ammonia concentration was hypothesised to be stripped from the system.

$\mathrm{NH}_{3}=\frac{N H_{4}}{1+10^{-p H+0.09018+\frac{2729.92}{T+273}}}$

where $\mathrm{NH}_{4}$ is the concentration of ammonium in the system; $\mathrm{pH}$ is the $\mathrm{pH}$ value of the culture and $\mathrm{T}$ is the culture temperature $\left({ }^{\circ} \mathrm{C}\right)$.

The duty cycle $(\varphi)$; i.e. the proportion of time at which microalgae are exposed to light (Fernández-Sevilla et al., 2018) can be calculated according to [Eq. 4]:

$\varphi=\frac{I_{a v}}{I_{0}}=\frac{\left(1-e^{-K_{a} \cdot C_{b} \cdot L}\right)}{K_{a} \cdot C_{b} \cdot L}$

where $I_{a v}$ is the average irradiance inside the PBRs $\left(\mu \mathrm{mol} \cdot \mathrm{m}^{-2} \cdot \mathrm{s}^{-1}\right), I_{0}$ is the light irradiance applied to the PBR surface $\left(\mu \mathrm{mol} \cdot \mathrm{m}^{-2} \cdot \mathrm{s}^{-1}\right), \mathrm{K}_{\mathrm{a}}$ is the extinction coefficient of the microalgae biomass $\left(\mathrm{m}^{2} \cdot \mathrm{g}^{-1}\right), \mathrm{C}_{\mathrm{b}}$ is the biomass concentration of the culture $\left(\mathrm{g} \cdot \mathrm{m}^{3}\right)$ and $\mathrm{L}$ is the light path of the PBR (m).

The amount of nitrous acid was obtained by the acid-base equilibrium [Eq. 5]:

$K_{a c}=\frac{\left[\mathrm{H}^{+}\right]\left[\mathrm{NO}_{2}\right]}{\left[\mathrm{HNO}_{2}\right]}$

where $\mathrm{K}_{\mathrm{ac}}$ is the acid dissociation constant for the $\mathrm{NO}_{2} / \mathrm{HNO}_{2}$ equilibrium $\left(\mathrm{pK}_{\mathrm{ac}}=3.4\right.$ at $25^{\circ} \mathrm{C}$, Blackburne et al., 2007); while $\left[\mathrm{H}^{+}\right],\left[\mathrm{NO}_{2}\right]$ and $\left[\mathrm{HNO}_{2}\right]$ are the concentration of protons, nitrite and nitrous acid, respectively, in the dissolution. 


\subsection{Statistical analysis}

All the results are shown as mean \pm standard deviation of the duplicates. STATGRAPHICS Centurion XVI.I was employed to perform ANOVA analysis. In this respect, $\mathrm{p}$-values $<0.05$ were considered statistically significant.

\section{Results and discussion}

\subsection{Outdoor MPBR plant}

Previous studies have evaluated the best conditions of the MPBR plant in terms of light availability, nutrient recovery and treatment capacity (González-Camejo et al., 2018; 2019a; 2019b). However, the operating conditions that enhance microalgae activity within the microalgae-AOB competition for ammonium uptake in the treatment of AnMBR effluents have not been appropriately assessed.

MPBR performance was evaluated in terms of NRR and biomass productivity. These parameters are commonly used to evaluate outdoor microalgae cultivation systems (Galès et al., 2019; Marazzi et al., 2019). To assess the activity of nitrifying bacteria, the nitrification rate (NOxR), i.e. the production rate of both nitrite and nitrate in the culture, was used (Rossi et al, 2018). It must be noted that this value disregards the nitrate and nitrite that algae can consume (Gupta et al., 2019). However, previous labscale assays showed that the nitrite and nitrate that microalgae assimilate was considerably lower than that of ammonium (González-Camejo et al., 2019a), so that NOxR was considered as a good approximation for nitrifying bacteria activity, as observed by González-Camejo et al. (2020). 


\subsubsection{Effect of dilution rate}

DR-Period was operated at dilution rate of $0.3 \mathrm{~d}^{-1}$ (i.e. 3-d BRT), while HRT was set to 1 d. As can be seen in Figure 1a, until day 12 of DR-Period, the $\mathrm{NO}_{\mathrm{x}}$ concentration was low since nitrification rate during this time only accounted for $1.6 \pm 0.9 \mathrm{mg} \mathrm{N} \cdot \mathrm{L}^{-1} \cdot \mathrm{d}^{-1}$. In normal situations of sufficient light intensity and nutrient concentrations, microalgae outcompete AOB due to their greater capacity to consume ammonium (Galès et al., 2019; Marcilhac et al., 2014). Consequently, in this period microalgae became the predominant organism of the culture, showing high biomass concentrations of $749 \pm 38$ mg VSS $\mathrm{L}^{-1}$ (Figure 1b). After that moment, NOxR increased and nitrite thus accumulated (Figure 1a). Consequently, the microalgae biomass concentration decreased to values under $400 \mathrm{mg} \mathrm{VSS} \cdot \mathrm{L}^{-1}$ (Figure 1b). Furthermore, nitrate effluent concentration reached a maximum of $19.0 \mathrm{mg} \mathrm{N} \cdot \mathrm{L}^{-1}$ on day 30 (Figure 1a). Nitrate is absorbed by microalgae at lower rate than ammonium since it has to be internally reduced prior to be assimilated (Chen et al., 2009; González-Camejo et al., 2019a; Shoener et al., 2019).

The relatively high temperature during DR-Period (i.e. $24.7 \pm 1.2{ }^{\circ} \mathrm{C}$ ) could have favoured $\mathrm{AOB}$ growth over microalgae since $\mathrm{AOB}$ are known to significantly increase their activity with increasing temperatures (González-Camejo et al., 2019a; 2020). For this, on day 31 (displayed in Figure 1 as dashed line), a punctual increase in the dilution rate from 0.3 to $0.5 \mathrm{~d}^{-1}$ was done in order to washout the culture and decrease the AOB, nitrite and nitrate concentrations. This changed the culture characteristics significantly, which probably made microalgae more competitive than nitrifying bacteria. In fact, some authors (Luo et al., 2018) have reported that higher dilution rates can stimulate microalgae growth by reducing the microalgae biomass concentration since it increases the culture's light availability (Fernández-Sevilla et al., 2018). 


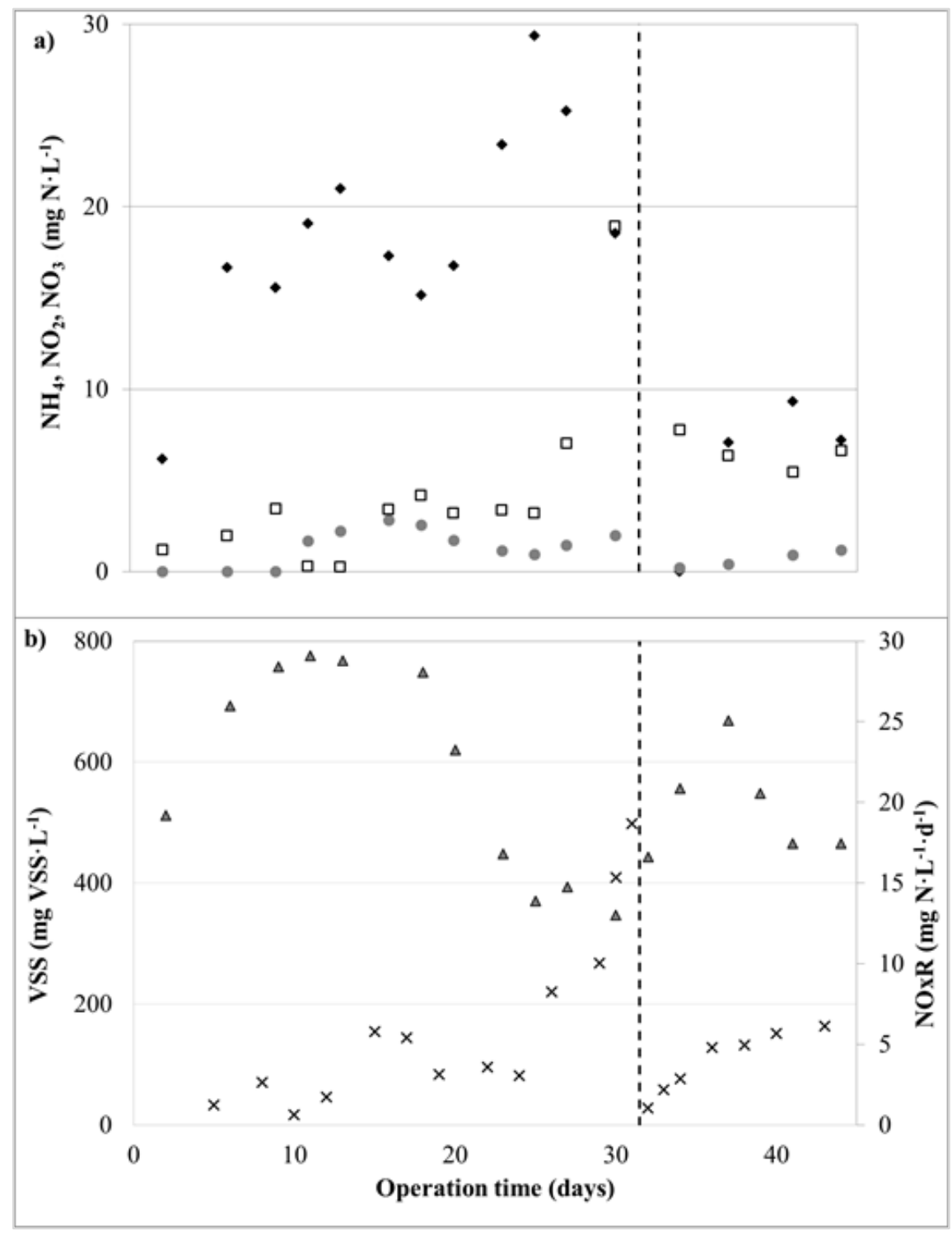

Figure 1. Continuous operation of the MPBR plant during DR-Period. Evolution of: a) effluent concentration of ammonium $\left(\mathrm{NH}_{4}\right)(\diamond)$, nitrite $\left(\mathrm{NO}_{2}\right)(\bullet)$ and nitrate $\left(\mathrm{NO}_{3}\right)(\square)$; and $b)$ concentration of the volatile suspended solids (VSS) ( $\Delta)$ and nitrification rate $(N O x R)(x)$. Punctual increase of dilution rate (- - -).

After this increase in the dilution rate, the MPBR plant continued operating at the same conditions (i.e. 3-d BRT and 1-d HRT) and the NOxR significantly decreased (Figure 1b). However, AOB started outcompeting microalgae again since the NOxR continuously rose after the punctual increase in the dilution rate. It can be therefore 
concluded that a sudden increase in the MPBR dilution rate can temporarily benefit microalgae by reducing the concentration of $\mathrm{AOB}$, nitrite and nitrate, but if operating conditions are not appropriate for microalgae growth, AOB will increase their activity again.

\subsubsection{Effect of BRT}

Period BRT-2 was operated at 2-d BRT. Under these conditions, AOB activity was favoured in comparison to microalgae since more influent nitrogen was nitrified instead of being assimilated by microalgae (Figure 2a). NOB activity was also low in Period BRT-2, which entailed nitrite to accumulate until reaching concentrations over $10 \mathrm{mg}$ $\mathrm{N} \cdot \mathrm{L}^{-1}$ from day 16 until the end of the Period (Figure 3a). The reduced NOB activity was not due to oxygen limitation, as occurred in other studies (see, for instance, Kwon et al., 2019) as oxygen concentration in the MPR was maintained at $11.6 \pm 0.9 \mathrm{mg} \mathrm{O}_{2} \cdot \mathrm{L}^{-}$

${ }^{1}$ during BRT periods (over oxygen saturation point). On the other hand, the low BRT of $2 \mathrm{~d}$ was likely to be too short for NOB to grow (Munz et al., 2011). Similar results were obtained by Marazzi et al. (2019), who reported higher nitrite concentrations at shorter BRTs in a mixed microalgae-bacteria culture for outdoor centrate treatment.

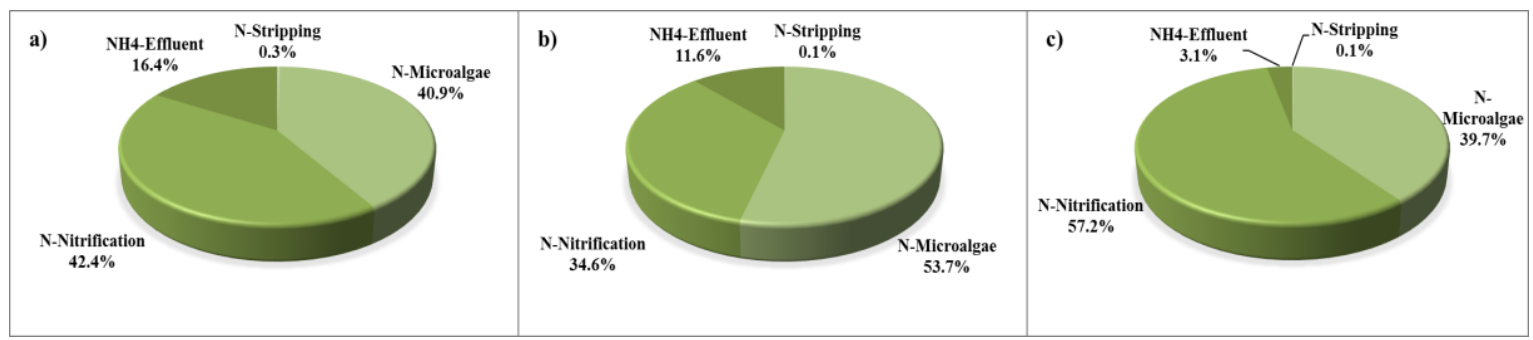

Figure 2. Distribution of nitrogen in the MPBR plant: a) Period BRT-2; b) Period BRT2.5; and c) Period BRT-4.5. 


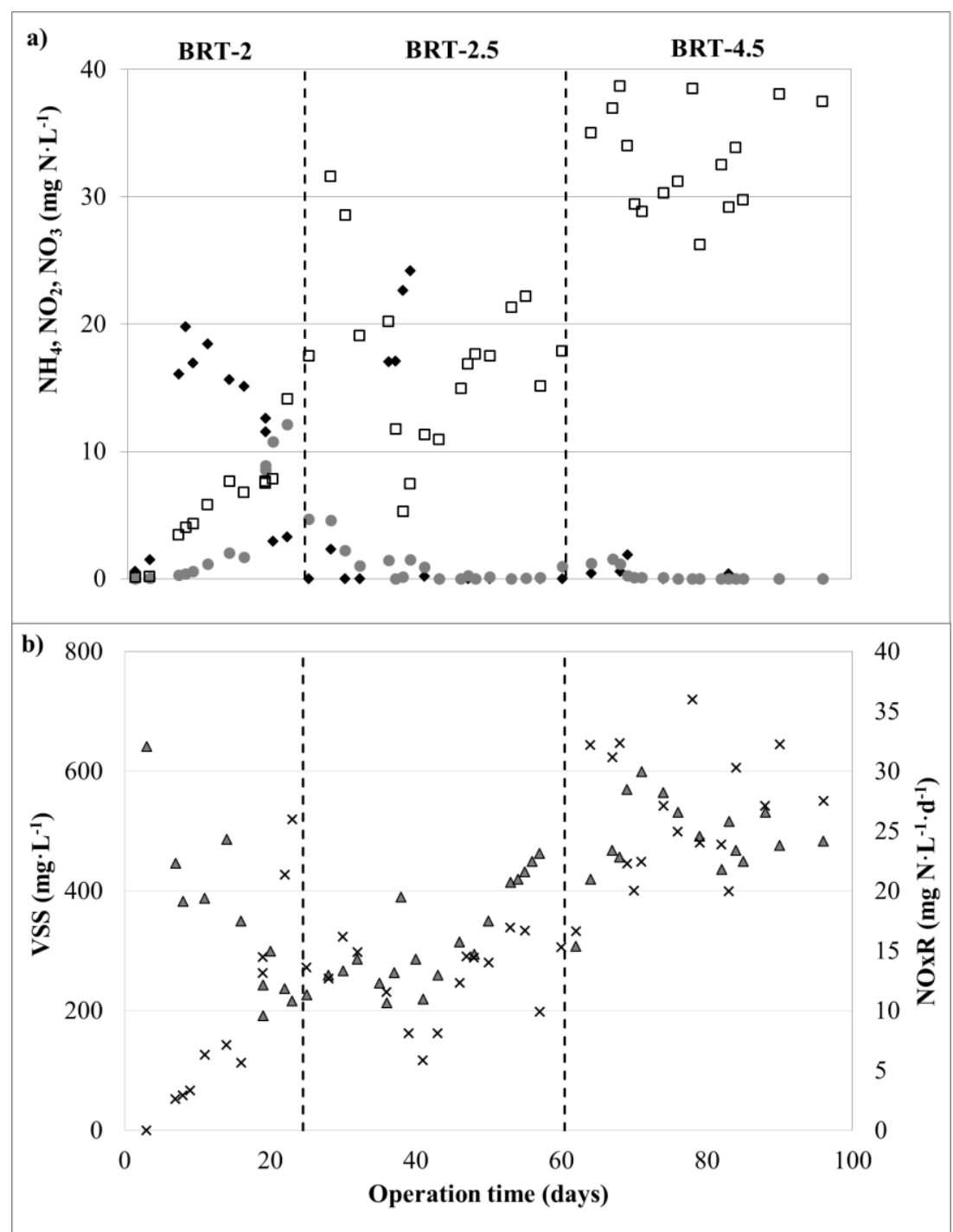

Figure 3. Continuous operation of the MPBR plant during BRT periods. Evolution of: a) effluent concentration of ammonium $\left(\mathrm{NH}_{4}\right)(\diamond)$, nitrite $\left(\mathrm{NO}_{2}\right)(\bullet)$ and nitrate $\left(\mathrm{NO}_{3}\right)$

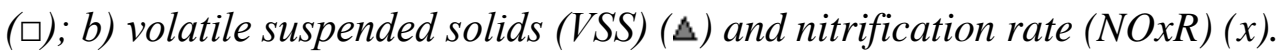

According to lab-scale assays (section 3.2.2), these nitrite concentrations should have inhibited microalgae activity. Consequently, the lowest MPBR performance in terms of NRR was obtained in Period BRT-2 (Table 3). Period BRT-2 also showed the highest percentage of nitrogen lost in the effluent, i.e. $58.8 \pm 20.0 \%$ (considering $\mathrm{N}$-nitrification plus $\mathrm{NH}_{4}$-Effluent, see Figure 2a). Hence, operating at 2-d BRT did not seem to be suitable for operating the microalgae-nitrifying bacteria culture in the MPBR plant since 
it triggered $\mathrm{AOB}$ activity, promoting nitrite accumulation and the subsequent microalgae inhibition.

Table 3. Biomass productivity, nutrient recovery and nitrification rates obtained in BRT periods.

\begin{tabular}{ccccc}
\hline Period & $\begin{array}{c}\text { Biomass productivity } \\
\left(\mathbf{m g ~ V S S} \cdot \mathbf{L}^{-\mathbf{1}} \cdot \mathbf{d}^{-\mathbf{1}}\right)\end{array}$ & $\begin{array}{c}\text { NRR } \\
\left(\mathbf{m g ~ N} \cdot \mathbf{L}^{-\mathbf{1}} \cdot \mathbf{d}^{-\mathbf{1}}\right)\end{array}$ & $\begin{array}{c}\text { NOxR } \\
\left(\mathbf{m g ~ N} \cdot \mathbf{L}^{-\mathbf{1}} \cdot \mathbf{d}^{-\mathbf{1}}\right)\end{array}$ & Duty cycle (-) \\
\hline BRT-2 & $136 \pm 53$ & $14.1 \pm 5.2$ & $14.4 \pm 1.5$ & $0.18 \pm 0.05^{*}$ \\
BRT-2.5 & $139 \pm 35$ & $19.7 \pm 3.3^{*}$ & $13.5 \pm 3.4$ & $0.15 \pm 0.04^{*}$ \\
BRT-4.5 & $108 \pm 26^{*}$ & $14.5 \pm 6.7$ & $27.1 \pm 4.9^{*}$ & $0.11 \pm 0.01^{*}$ \\
\hline
\end{tabular}

*Showed significant differences ( $p$-value $<0.05)$

In Period BRT-2.5, BRT was raised to $2.5 \mathrm{~d}$. As a consequence, the nitrite concentration sharply decreased from $12.2 \mathrm{mg} \mathrm{N} \cdot \mathrm{L}^{-1}$ to values lower than $1 \mathrm{mg} \mathrm{N} \cdot \mathrm{L}^{-1}$ from day 41 on (Figure 3a). As aforementioned, 2-d BRT was too short for NOB to grow, but increasing BRT to 2.5 d favoured them (Marazzi et al., 2019; Munz et al., 2011), causing the nitrite depletion in the culture by carrying out the second step of nitrification (Winkler and Straka, 2019). Once nitrite was oxidised by NOB, microalgae were able to grow as they were no longer inhibited by nitrite, which allowed biomass concentration to grow significantly from $266 \pm 51 \mathrm{mg} \mathrm{VSS} \cdot \mathrm{L}^{-1}$ in days $24-41$ to $378 \pm$ $74 \mathrm{mg} \mathrm{VSS} \cdot \mathrm{L}^{-1}$ from day 42 until the end of Period BRT-2.5 (p-value $<0.05$ ). As a result, nitrification was reduced and the nitrogen used for microalgae biomass rose up to $53.7 \pm 11.4 \%$ of the influent nitrogen, while total effluent nitrogen concentration (i.e. ammonium plus nitrified nitrogen, $\mathrm{NO}_{2}$ and $\mathrm{NO}_{3}$ ) only accounted for $46.2 \pm 21.1 \%$ (Figure 2b), much lower than that of Period BRT-2: $58.8 \pm 20.0 \%$. These results highlight the importance of operating conditions on microalgae-nitrifying competition 
since nitrification can account for up to $85 \%$ of the total influent nitrogen in microalgaebacteria consortia (Gupta et al., 2019). Consequently, MPBR yields (i.e. NRR and biomass productivity) in Period BRT-2.5 were the best of BRT periods (Table 3).

In Period BRT-4.5, BRT was lengthened to $4.5 \mathrm{~d}$. Similar to what happened in Period BRT-2.5, no nitrite accumulation was observed during Period BRT-4.5 (Figure 3a), probably because NOB growth was favoured at longer BRTs (Munz et al., 2011). Microalgae growth was not thus expected to be inhibited by nitrite. However, the nitrogen assimilated by microalgae only accounted for $39.7 \pm 15.7 \%$ (Figure $2 \mathrm{c}$ ), which made total nitrogen in the effluent rise to $60.3 \pm 32.5 \%$. Consequently, the highest NOxR and nitrogen concentration in the MPBR effluent were observed in Period BRT4.5 (Table 3). This could have occurred for several reasons:

i) The significantly high nitrification (i.e. $57.2 \pm 20.5 \%$ of the influent nitrogen) made most of the nitrogen be in the form of nitrate. It is widely known that nitrate uptake rate by microalgae is significantly lower than that of ammonium (González-Camejo et al., 2019a; Shoener et al., 2019).

ii) To assimilate nitrate into microalgae biomass, microalgae need to prior reduce it to nitrite (by enzyme nitrate reductase in the cytosol), and nitrite to ammonium (by nitrite reductase in the chloroplast). According to Chen et al. (2009), large amounts of nitrate in the culture increases nitrate reductase activity in a greater manner than nitrite reductase, which can cause the intracellular accumulation of nitrite. This intracellular nitrite was hypothesised to inhibit cyanobacteria Microcystis aeroginosa (Chen et al., 2009) and could have thus been responsible for the inhibition of Chlorella in the microalgae-nitrifying bacteria culture of this study.

iii) The negligible ammonium concentration during Period BRT-4.5 (Figure 3a) was likely to reduce microalgae growth due to nutrient limitation, favouring nitrification. In 
fact, outdoor tests carried out under ammonium replete and deplete conditions (see Supplementary material) showed that NOxR sharply increased from $1.3 \pm 2.2 \mathrm{mg} \mathrm{N} \cdot \mathrm{L}^{-}$ ${ }^{1} \cdot \mathrm{d}^{-1}$ to $17.5 \pm 5.3 \mathrm{mg} \mathrm{N} \cdot \mathrm{L}^{-1} \cdot \mathrm{d}^{-1}$ under replete and deplete-ammonium conditions, respectively.

iv) The shadow effect caused by the significant biomass increase: from $347 \pm 84 \mathrm{mg}$ VSS $\cdot \mathrm{L}^{-1}$ in Period BRT-2.5 to $486 \pm 70 \mathrm{mg} \mathrm{VSS} \cdot \mathrm{L}^{-1}$ in Period BRT-4.5 (p-value < 0.05). The rising amount of microalgae biomass absorbed most of light photons, reducing the time which microalgae spent under lighting conditions significantly (Fernández-Sevilla et al., 2018). As a consequence, the lowest duty cycle of BRT periods was obtained in Period BRT-4.5 (Table 3).

It must be noted that temperature effect in the microalgae-AOB competition was not considered in BRT periods since it remained at moderate temperatures (Table 1) at which AOB growth is usually lower than that of microalgae (González-Camejo et al., 2019a). The possible inhibition of nitrifying bacteria due to excessive light irradiance (Akizuki et al., 2019b; Vergara et al., 2016) was not evaluated either since solar PAR remained at fairly constant values in all BRT periods (Table 1).

To sum up, BRT apparently had a significant influence on the microalgae-AOB competition for ammonium uptake. In this respect, too short BRTs of $2 \mathrm{~d}$ seemed to favour $\mathrm{AOB}$ activity in comparison to microalgae and $\mathrm{NOB}$, causing the nitrite accumulation and the subsequent microalgae inhibition by nitrite. On the other hand, long BRT of $4.5 \mathrm{~d}$ favoured NOB growth, therefore oxidising nitrite and accumulating nitrate. However, these operating conditions resulted in a lower NRR and biomass productivity than those obtained working at 2.5-d BRT. Operating the MPBR plant at 2.5-d BRT also showed the lowest amount of nitrogen in the effluent: $46.2 \pm 21.1 \%$. In conclusion, appropriate BRT range must be operated in outdoor microalgae-nitrifying 
bacteria cultivation systems to obtain more efficient treatment of nutrient-enriched AnMBR effluents. According to the results of this study, this BRT range must fall within 2-4.5 d.

\subsection{Nitrite inhibition}

\subsubsection{Short-term exposure to nitrite}

A first approach on the evaluation of nitrite inhibition (at lab-scale) was carried out by respirometries, which allowed obtaining the OPR of microalgae. OPR was selected as an indicator of microalgae performance as it has been widely reported to be proportional to microalgae photosynthetic activity (Rossi et al., 2018).

Four different nitrite concentrations were tested in the reactor: $0,5,10$ and $20 \mathrm{mg} \mathrm{N} \cdot \mathrm{L}^{-1}$, which corresponded to $\mathrm{R}_{0}, \mathrm{R}_{5}, \mathrm{R}_{10}$ and $\mathrm{R}_{20}$ assays, respectively. Higher nitrite concentrations were not tested since the outdoor MPBR plant was not likely to present such concentrations. In addition, previous experimental periods carried out in the MPBR plant showed that microalgae did not seem to be affected by nitrite concentrations lower than $5 \mathrm{mg} \mathrm{N} \cdot \mathrm{L}^{-1}$ (data not shown).

It must be noted that the OPR obtained by Eq. 1 corresponds to a net value which is the result of several processes: i) microalgae photosynthesis; ii) activity of nitrifying bacteria; iii) respiration of heterotrophic bacteria; and iv) microalgae photorespiration (Rossi et al., 2018).

However, AOB activity was inhibited by ATU addition (section 2.2.1.1). In addition, continuous monitoring of the MPBR operations by the respirometric methodology of Rossi et al. (2018) (data not shown) showed that the sum of heterotrophic bacteria activity and microalgae photorespiration accounted for $10.7 \%$ of the total microalgae photosynthetic activity ( $\mathrm{p}$-value $<0.05 ; \mathrm{R}^{2}=0.672 ; \mathrm{n}=6$ ); although the activity of 
heterotrophic bacteria was expected to be negligible in this system due to the low biochemical oxygen demand of the AnMBR effluent, which only accounted for $29 \pm 4$ $\mathrm{mg} \mathrm{O}_{2} \cdot \mathrm{L}^{-1}$. Moreover, as the inoculum used for all the respirometric tests was the same, microalgae photorespiration and heterotrophic bacteria activity was expected to affect all the tests at similar rate. In conclusion, the net OPR obtained by Eq. 1 was considered as representative measurement of the microalgae activity.

OPRs varied in the range of $30.0-34.4 \mathrm{mg} \mathrm{O} \mathrm{O}_{2} \cdot \mathrm{L}^{-1} \cdot \mathrm{d}^{-1}$ (Figure 4), which means that no statistically significant differences (p-value > 0.05) were observed in photosynthetic activity of microalgae when they were exposed to nitrite concentrations in the range of 5-20 $\mathrm{mg} \mathrm{N} \cdot \mathrm{L}^{-1}$ during 30 minutes (short-term).

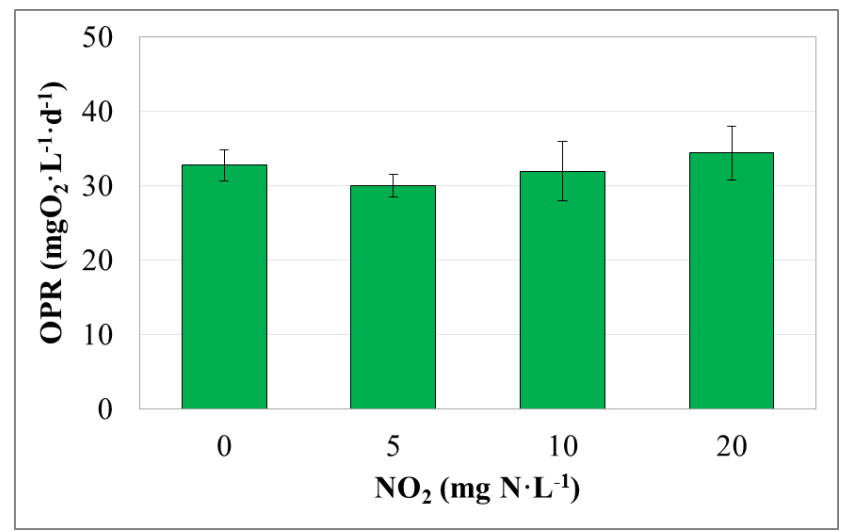

Figure 4. Oxygen production rates (OPR) $\left(\mathrm{mg} \mathrm{O}_{2} \cdot \mathrm{L}^{-1} \cdot d^{-1}\right)$ obtained during the respirometric tests (short-term exposure to nitrite).

\subsubsection{Continuous exposure to nitrite}

Figure 5 shows the results of the continuous lab-scale assays. It can be observed that NRRs were considerably lower in R-B (with the presence of $\mathrm{NO}_{2}$ ) than in R-A (control, negligible $\mathrm{NO}_{2}$ concentration), and that the difference between $\mathrm{R}-\mathrm{A}$ and $\mathrm{R}-\mathrm{B}$ increased when nitrite concentration in R-B was higher. In fact, NRR in R-B was $32 \%$ lower than 
R-A for Assay $L_{5}$, while for Assays $\mathrm{L}_{10}$ and $\mathrm{L}_{20}$ NRR was reduced by 42 and $80 \%$, respectively.
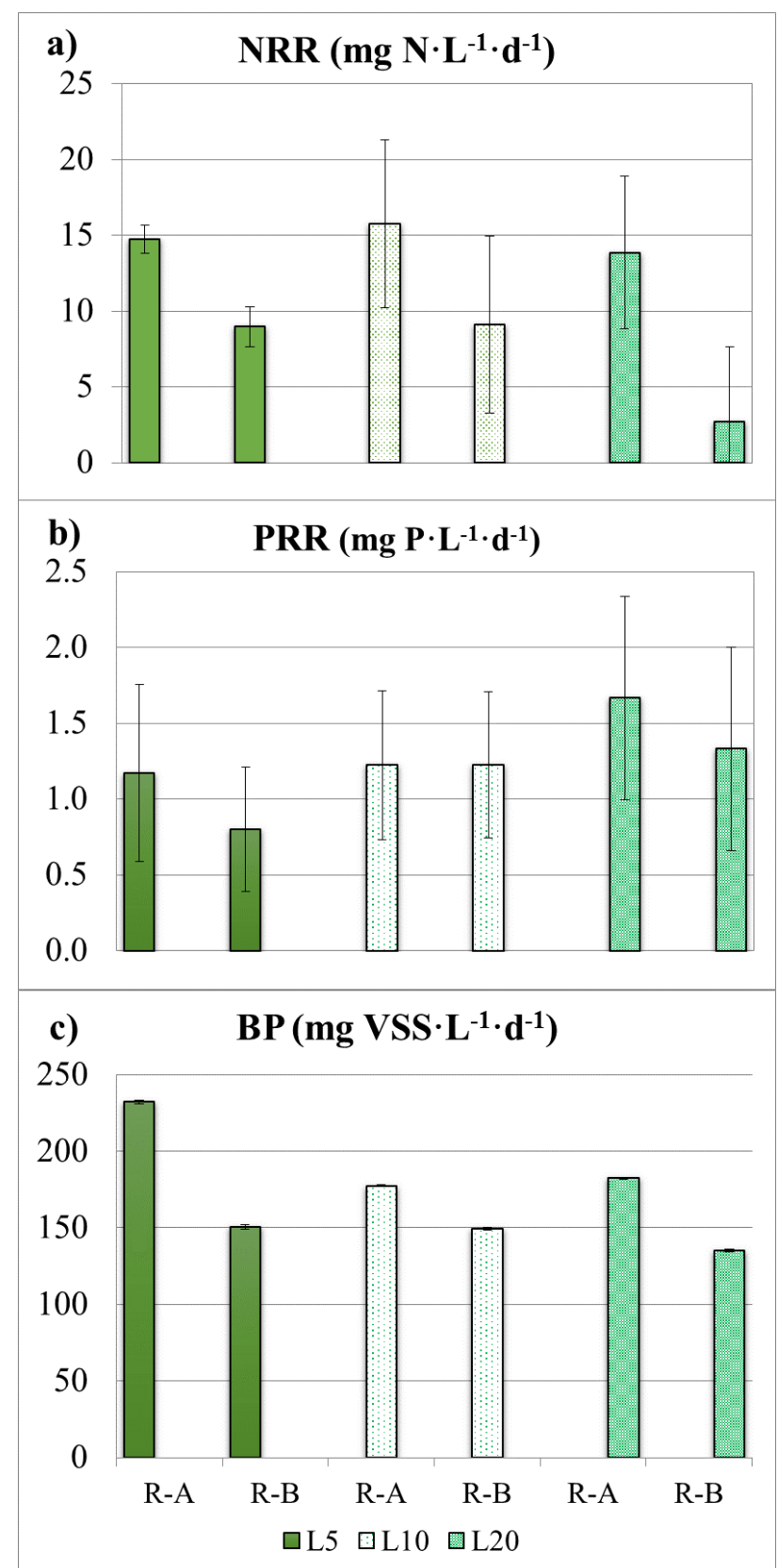

Figure 5. Results from continuous lab-scale assays. $R$-A: without the presence of nitrite, and $R-B:$ with the presence of nitrite $\left(5,10\right.$ and $\left.20 \mathrm{mg} \mathrm{N}-\mathrm{NO}_{2} \cdot \mathrm{L}^{-1}\right):$ a) nitrogen recovery rate (NRR); b) phosphorus recovery rate (PRR) and c) biomass productivity $(B P)$. 
On the other hand, PRR showed a 32\% difference between R-A and R-B in Assay $\mathrm{L}_{5}$, but for Assays $\mathrm{L}_{10}$ and $\mathrm{L}_{20}$ the results were similar, probably due to the phosphorus limitation during Assays $\mathrm{L}_{10}$ and $\mathrm{L}_{20}$ (Figure 6). In fact, the culture sample in these assays was phosphorus-lacking (Table 2). On the contrary, during Assay $\mathrm{L}_{5}$ the culture was under phosphorus-replete conditions (Figure 6).
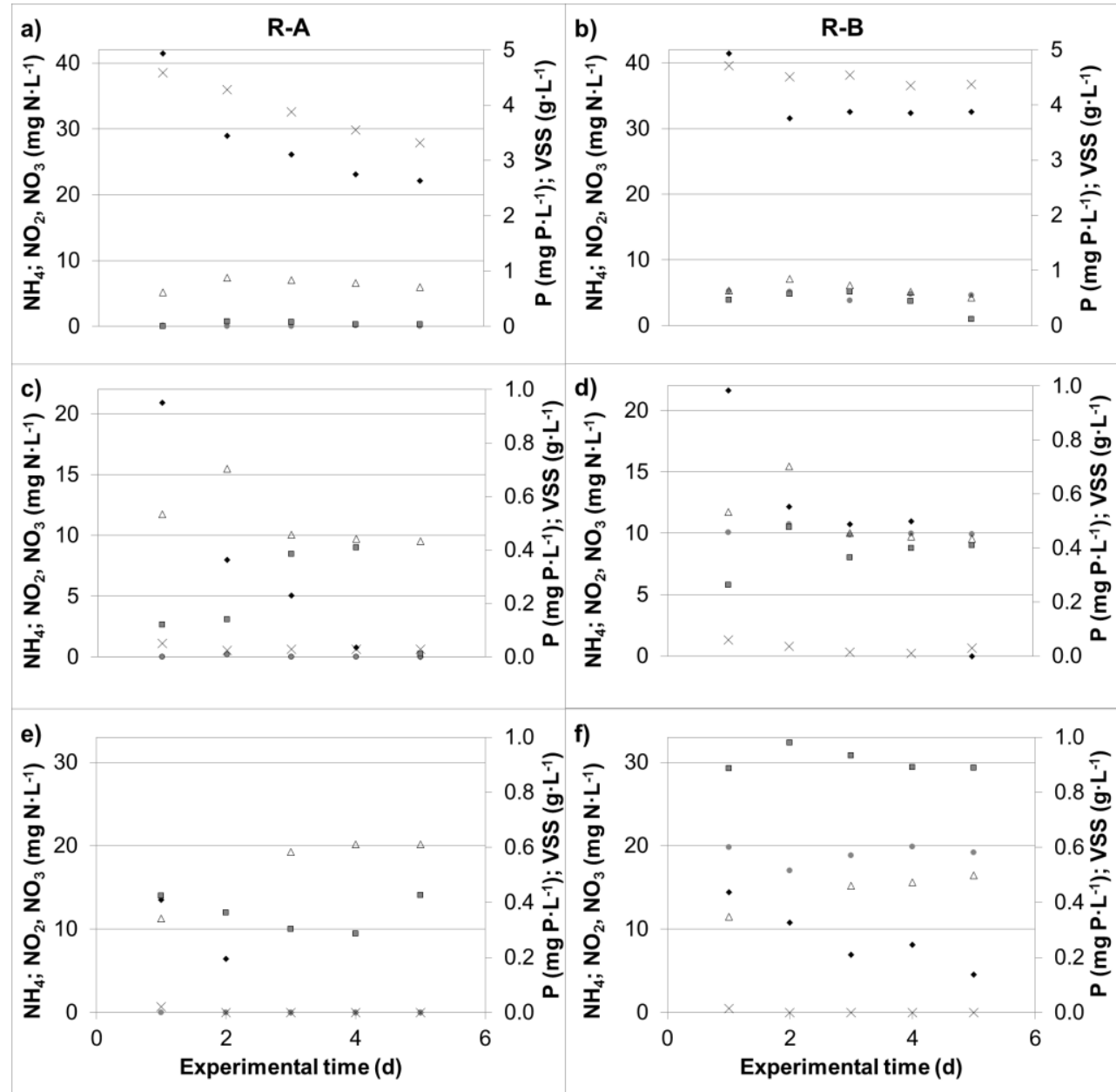

Figure 6. Evolution of ammonium $\left(\mathrm{NH}_{4}\right)(\diamond)$; nitrite $\left(\mathrm{NO}_{2}\right)(\bullet)$, phosphorus $(\mathrm{P})(x)$ and volatile suspended solids (VSS) $(\triangle)$ concentration during continuous lab-scale assays: a) $R$-A in Assay $L_{5}$ (control); b) $R-B$ in Assay $L_{5}\left(N O_{2}=5 \mathrm{mg} \mathrm{N} \cdot L^{-1}\right)$; c) $R-A$ in Assay $L_{10}$ (control); d) R-B in Assay $L_{10}\left(N O_{2}=10 \mathrm{mg} \mathrm{N} \cdot \mathrm{L}^{-1}\right)$; e) $R$-A in Assay L $L_{20}$ (control); and f)

$$
R-B \text { in Assay } L_{20}\left(N_{2}=20 \mathrm{mg} \mathrm{N} \cdot L^{-1}\right) \text {. }
$$


Regarding microalgae biomass, R-A obtained significantly higher biomass productivities than R-B in all the continuous lab-scale assays, but unlike NRR, the differences in biomass productivities between R-A and R-B did not raise with increasing $\mathrm{NO}_{2}$ concentration. Indeed, biomass productivity in R-B was 35, 16 and 19\% lower than in R-A for Assays $\mathrm{L}_{5}, \mathrm{~L}_{10}$ and $\mathrm{L}_{20}$, respectively. This different trend was probably due to the nutrient limitation observed in Assays $\mathrm{L}_{10}$ and $\mathrm{L}_{20}$; i.e. $\mathrm{NH}_{4}<10 \mathrm{mg}$ $\mathrm{N} \cdot \mathrm{L}^{-1}$ and $\mathrm{P}<1 \mathrm{mg} \mathrm{P} \cdot \mathrm{L}^{-1}$ (González-Camejo et al., 2019b). Anyhow, the nitrite inhibition of microalgae was observed in all the continuous lab-scale assays, which confirmed what was observed in the MPBR plant operation (Section 3.1); i.e. nitrite concentrations over $5 \mathrm{mg} \mathrm{N} \cdot \mathrm{L}^{-1}$ showed inhibitory effects on a microalgae-nitrifying bacteria culture dominated by Chlorella. It must be highlighted that this concentration is similar to that reported by Admiraal (1977), who observed growth inhibition of ten diatoms at $10 \mathrm{mg} \mathrm{N}-\mathrm{NO}_{2} \cdot \mathrm{L}^{-1}$, but quite lower than the $70 \mathrm{mg} \mathrm{N}-\mathrm{NO}_{2} \cdot \mathrm{L}^{-1}$ which were inhibitory for Botryococcus braunii (Yang et al., 2004).

These results can help to clarify the behaviour of the microalgae-nitrifying bacteria culture during the continuous operation of the MPBR plant. The reduction of MPBR plant performance after an AOB proliferation was previously thought to occur because of ammonium depletion due to nitrification (González-Camejo et al., 2018) or because of competitive exclusion between microalgae and bacteria (González-Camejo et al., 2019a). Results obtained in this study therefore add another factor related to AOB activity that negatively affects MPBR performance. In this respect, it must be noted that nitrite is not a permanent inhibitor since it does not completely stop microalgae activity but reduces it, so that short-term exposures to nitrite probably did not produce significantly different photosynthetic activities (see section 3.2.1). However, when the 
microalgae were continuously exposed to nitrite, their cumulative effects became noticeable.

It should be also considered that under this continuous exposure to nitrite, microalgae were also exposed to nitrous acid. According to acid-base equilibrium, under $\mathrm{pH}$ values of $7.3 \pm 0.2$, temperature of around $25^{\circ} \mathrm{C}$ and nitrite concentrations of 5,10 and $20 \mathrm{mg}$ $\mathrm{N} \cdot \mathrm{L}^{-1}, \mathrm{HNO}_{2}$ concentration would account for $0.6 \pm 0.2,1.3 \pm 0.5$ and $2.5 \pm 1.0 \mu \mathrm{g} \mathrm{N} \cdot \mathrm{L}^{-}$ ${ }^{1}$, respectively. Since the inhibitory concentration for AOB/NOB has been reported to be 200/30 $\mu \mathrm{g} \mathrm{N} \cdot \mathrm{L}^{-1}$, respectively (Anthonisen et al., 1976; Blackburne et al., 2007), these significantly lower $\mathrm{HNO}_{2}$ concentrations were not expected to inhibit microalgae, which are more complex microorganisms than NOB. Further research would be needed to assess the $\mathrm{HNO}_{2}$ concentration that inhibits microalgae.

It must be also noted that the possibility that different microalgae performance in R-A and R-B were due to other microorganisms such as $\mathrm{AOB} / \mathrm{NOB}$ was discarded for the following reasons: i) AOB was inhibited by ATU addition (see Section 2.2.2.2); ii) nitrifying bacteria activity in a similar culture dominated by Chlorella only accounted for $4.4 \%$ (on average) of microalgae activity (data not shown). NOB activity could thus be considered negligible; iii) nitrogen recovery rates were observed to decrease with higher nitrite concentrations (i.e. from 5 to $20 \mathrm{mg} \mathrm{N} \cdot \mathrm{L}^{-1}$ ). However, according to the half saturation constant of $\mathrm{NOB}$ with respect to $\mathrm{NO}_{2}$, i.e. $0.3 \mathrm{mg} \mathrm{N} \cdot \mathrm{L}^{-1}$ according to Jiménez (2010), under nitrite concentration of $5 \mathrm{mg} \mathrm{N} \cdot \mathrm{L}^{-1} \mathrm{NOB}$ activity would be close to their optimum. Differences in NOB activity under nitrite concentrations in the range of 5-20 mg N.L $\mathrm{L}^{-1}$ should hence be negligible. In consequence, differences in microalgae performance under different nitrite concentrations might not have been due to NOB activity. 


\section{Conclusions}

The continuous operation under outdoor conditions showed that BRT played a key role in the nitrite accumulation in the microalgae-nitrifying bacteria culture (dominated by Chlorella). At BRT of $2 \mathrm{~d}$, AOB were favoured and nitrite accumulated.

Lab-scale assays confirmed that this culture was inhibited by nitrite under continuous treatment of AnMBR effluent. In fact, nitrogen recovery was reduced by 32, 42 and $80 \%$ (in comparison to the reactor control) for nitrite concentrations of 5, 10 and $20 \mathrm{mg}$ $N \cdot L^{-1}$, respectively. On the other hand, no significant differences were observed in the photosynthetic activity when microalgae were exposed to nitrite concentrations of 5,10 and $20 \mathrm{mg} \mathrm{N} \cdot \mathrm{L}^{-1}$ during 30 minutes.

When BRT of the MPBR plant was lengthened to $2.5 \mathrm{~d}$, nitrite was reduced due to increasing microalgae and NOB activity. MPBR performance was thus enhanced, reaching maximum NRR of $19.7 \pm 3.3 \mathrm{mg} \mathrm{N} \cdot \mathrm{L}^{-1} \cdot \mathrm{d}^{-1}$ and biomass productivity of $139 \pm$ $35 \mathrm{mg} \mathrm{VSS} \cdot \mathrm{L}^{-1} \cdot \mathrm{d}^{-1}$.

Operating the MPBR plant at long BRT of $4.5 \mathrm{~d}$ did not show any nitrite accumulation since it was fully oxidised to nitrate. Under these conditions, microalgae activity was limited due to several possible reasons: i) microalgae prefer ammonium instead of nitrate; ii) possible accumulation of intracellular nitrite which could have inhibited microalgae; iii) ammonium-deplete conditions which limited microalgae activity; and iv) shadow effect that reduced light availability.

Summarising, if maximum MPBR performance wants to be reached, BRT should be maintained between 2-4.5 d. This way microalgae growth would be favoured in comparison to AOB and NOB. 


\section{Acknowledgments}

This research work was supported by the Spanish Ministry of Economy and Competitiveness (MINECO, Projects CTM2014-54980-C2-1-R and CTM2014-54980C2-2-R) jointly with the European Regional Development Fund (ERDF), both of which are gratefully acknowledged. It was also supported by the Spanish Ministry of Education, Culture and Sport via a pre-doctoral FPU fellowship to authors J. GonzálezCamejo (FPU14/05082) and S. Aparicio (FPU/15/02595).

\section{E-supplementary data of this work can be found in online version of the paper.}

\section{References}

1. Abe, K., Imamaki, A., Hirano, M., 2002. Removal of nitrate, nitrite, ammonium and phosphate ions from water by the aerial microalga Trentepohlia aurea. J. Appl. Phycol. 14(2), 129-134. https://doi.org/10.1023/A:1019599216554

2. Admiraal, W., 1977. Tolerance of Estuarine Benthic Diatoms to High Concentrations of Ammonia, Nitrite Ion, Nitrate Ion and Orthophosphate. Marine Biology 43, 307-315

3. Akizuki, S., Cuevas-Rodriguez, G., Toda, T., 2019a. Microalgal-nitrifying bacterial consortium for energy-saving ammonia removal from anaerobic digestate of slaughterhouse wastewater. J. Water Process Eng. 31, 100753. https://doi.org/10.1016/j.jwpe.2019.01.014

4. Akizuki, S., Kishi, M., Cuevas-Rodríguez, G., Toda, T., 2019b. Effects of different light conditions on ammonium removal in a consortium of microalgae and partial nitrifying granules. Water Res. (in press) https://doi.org/10.1016/j.watres.2019.115445 
5. Almeida, J.S., Júlio, S.M., Reis, M.A.M., Carrondo, M.J.T., 1995. Nitrite inhibition of denitrification by Pseudomonas fluorescens. Biotechnol. Bioeng. 46:194-201. https://doi.org/10.1002/bit.260460303

6. Anthonisen, A.C., Srinath, E.G., Loehr, R.C., Prakasam, T.B.S., 1976. Inhibition of nitrification and nitrous acid compounds. J. Water Pollut. Control Fed. 48(5), $835-852$.

7. APHA-AWWA-WPCF, 2005. Standard methods for the examination of water and wastewater, $21^{\text {st }}$ edition. American Public Health Association, American Water Works Association, Water Pollution Control Federation. Washington DC, USA.

7. Bilad, M.R., Azizo, A.S., Wirzal, M.D.H., Jia, L.J., Putra, Z.A., Nordin, NA.H.M., Mavukkandy, M.O., Jasni, M.J.F., Yusoff, A.R.M., 2018. Tackling membrane fouling in microalgae filtration using nylon 6,6 nanofiber membrane. J. Environ. Manag. 223, 23-28. https://doi.org/10.1016/j.jenvman.2018.06.007

8. Blackburne, R., Vadivelu, V.M., Yuan, Z., Keller, J., 2007. Kinetic characterisation of an enriched Nitrospira culture with comparison to $\begin{array}{llll}\text { Nitrobacter. } & \text { Water } & \text { Res. }\end{array}$ https://doi.org/10.1016/j.watres.2007.01.043

9. Chen, W. M., Zhang, Q. M., Dai, S. G., 2009. Utilization of nitrite as a nitrogen source by Microcystis aeruginosa. J. Agro-Environ. Sci. 28(5), 989-993. https://doi.org/10.1007/s10811-009-9405-1

10. Eze, V.C, Velasquez-Orta, S.B., Hernández-García, A., Monje-Ramírez, I., Orta-Ledesma, M.T., 2018. Kinetic modelling of microalgae cultivation for wastewater treatment and carbon dioxide sequestration. Algal Res. 32, 131-141. https://doi.org/10.1016/j.algal.2018.03.015 
11. Fernández-Sevilla, J.M., Brindley, C., Jiménez-Ruíz, N., Acién, F.G., 2018. A simple equation to quantify the effect of frequency of light/dark cycles on the photosynthetic response of microalgae under intermittent light. Algal Res. 35, 479-487. https://doi.org/10.1016/j.algal.2018.09.026

12. Galès, A., Bonnafous, A., Carré, C., Jauzein, V. Lanouguère, E., Le Floc'ha, E., Pinoit, J., Poullain, C., Roques, C., Sialve, B., Simier, M., Steyer, J.P., Fouilland, E., 2019. Importance of ecological interactions during wastewater treatment using High Rate Algal Ponds under different temperate climates, Algal Res. 40, 101508. https://doi.org/10.1016/j.algal.2019.101508

13. Gonçalves, A.L., Pires, J.C.M., Simões, M., 2017. A review on the use of microalgal consortia for wastewater treatment, Algal Res. 24, 403-415. http://dx.doi.org/10.1016/j.algal.2016.11.008

14. González-Camejo, J., Barat, R., Aguado, D., Ferrer, J., 2020. Continuous 3-year outdoor operation of a flat-panel membrane photobioreactor to treat effluent from an anaerobic membrane bioreactor. Water Res. 169, 115238. https://doi.org/10.1016/j.watres.2019.115238

15. González-Camejo, J., Aparicio, A., Ruano, M.V., Borrás, L., Barat, R., Ferrer, J., 2019a. Effect of ambient temperature variations on an indigenous microalgaenitrifying bacteria culture dominated by Chlorella. Bioresour. Technol. 290, 121788. https://doi.org/10.1016/j.biortech.2019.121788

16. González-Camejo, J., Jiménez-Benítez, A., Ruano, M.V., Robles, A., Barat, R., Ferrer, J., 2019b. Optimising an outdoor membrane photobioreactor for tertiary sewage treatment. J. Environ. Manag. 245, 76-85. https://doi.org/10.1016/j.jenvman.2019.05.010 
17. González-Camejo, J., Barat, R., Ruano, M.V., Seco, A., Ferrer, J., 2018. Outdoor flat-panel membrane photobioreactor to treat the effluent of an anaerobic membrane bioreactor. Influence of operating, design and environmental conditions. Water Sci. Technol. 78(1), 195-206. http://dx.doi.org/10.2166/wst.2018.259

18. Gupta S., Pawar, S.B., Pandey, R.A., 2019. Current practices and challenges in using microalgae for treatment of nutrient rich wastewater from agro-based $\begin{array}{lllll}\text { industries. } & \text { Sci. } & \text { Total } & \text { Environ. }\end{array}$ https://doi.org/10.1016/j.scitotenv.2019.06.115

19. Jiménez, E., 2010. Mathematical modelling of the two-stage nitrification process. Developement of modelling calibration methodologies for a SHARON reactor and activated sludge process (Modelación matemática del proceso nitrificación en dos etapas. Desarrollo de metodologías de calibración del modelo para un reactor SHARON y un proceso de fangos activados). $\mathrm{PhD}$ Thesis, Polytechnic University of Valencia, Spain.

20. Kwon, G., Kim, H., Song, C., Jahng, D., 2019. Co-culture of microalgae and enriched nitrifying bacteria for energy-efficient nitrification. Biochem. Eng. J. 152, 107385. https://doi.org/10.1016/j.bej.2019.107385

21. Luo, Y., Le-Clech, P., Henderson, R.K., 2018. Assessment of membrane photobioreactor (MPBR) performance parameters and operating conditions. Water Res. 138, 169-180. https://doi.org/10.1016/j.watres.2018.03.050

22. Marazzi, F., Bellucci, M., Rossi, S., Fornaroli, R., Ficara, E., Mezzanotte, V., 2019. Outdoor pilot trial integrating a sidestream microalgae process for the treatment of centrate under non optimal climate conditions. Algal Res. 39, 101430. https://doi.org/10.1016/j.algal.2019.101430 
22. Marcilhac, C., Sialve B., Pourcher A.M., Ziebal C., Bernet N., Béline F., 2014. Digestate color and light intensity affect nutrient removal and competition phenomena in a microalgal-bacterial ecosystem, Water Res. 64, 278-287. http://dx.doi.org/10.1016/j.watres.2014.07.012

23. Molinuevo-Salces, B., García-González, M.C., González-Fernández, C., 2010. Performance comparison of two photobioreactors configurations (open and closed to the atmosphere) treating anaerobically degraded swine slurry, $\begin{array}{llll}\text { Bioresour. } & \text { Technol. } & \text { 5144-5149. }\end{array}$ https://doi.org/10.1016/j.biortech.2010.02.006

24. Munz, G., Lubello, C., Oleszkiewicz, J.A., 2011. Factors affecting the growth rates of ammonium and nitrite oxidizing bacteria. Chemosphere, 83(5), 720-725. https://doi.org/10.1016/j.chemosphere.2011.01.058

26. Rada-Ariza, A.M., Fredy, D., Lopez-Vazquez, C.M., Van der Steen, N.P., Lens, P.N.L., 2019. Ammonium removal mechanisms in a microalgal-bacterial sequencing batch photobioreactor at different solids retention times. Algal Res. 39, 101468. https://doi.org/10.1016/j.algal.2019.101468

27. Rossi, S., Bellucci, M., Marazzi, F., Mezzanotte, V., Ficara, E., 2018. Activity assessment of microalgal-bacterial consortia based on respirometric tests. Water Sci Technol. 78(1), 207-215. https://doi.org/10.2166/wst.2018.078

28. Ruiz-Martínez, A., Martín García, N., Romero, I., Seco, A., Ferrer, J., 2012. Microalgae cultivation in wastewater: nutrient removal from anaerobic membrane bioreactor effluent. Bioresour. Technol. 126, 247-253. http://dx.doi.org/10.1016/j.biortech.2012.09.022 
29. Santos, F.M., Pires, J.C.M., 2018. Nutrient recovery from wastewaters by microalgae and its potential application as bio-char. Bioresour. Technol. 267, 725-731. https://doi.org/10.1016/j.biortech.2018.07.119

30. Seco, A., Aparicio, S., González-Camejo, J., Jiménez-Benítez, A., Mateo, O., Mora, J.F., Noriega-Hevia, G., Sanchis-Perucho, P., Serna-García, R., Zamorano-López, N., Giménez, J.B., Ruiz-Martinez, A., Aguado, D., Barat, R., Borrás, L., Bouzas, A., Martí, N., Pachés, M., Ribes, J., Robles, A., Ruano, M.V., Serralta, J. and Ferrer, J., 2018. Resource recovery from sulphate-rich sewage through an innovative anaerobic-based water resource recovery facility $\begin{array}{llll}\text { (WRRF). } & \text { Water } & \text { Sci. } & \text { Technol. }\end{array}$ https://doi.org/10.2166/wst.2018.492

31. Sijbesma, W.F.H., Almeida, J.S., Reis, M.A.M., Santos, H., 1996. Uncoupling effect of nitrite during denitrification by Pseudomonas fluorescens: an in vivo PNMR study. Biotechnol Bioeng 52, 176-192. http://dx.doi.org/1010.1002/(SICI)1097-0290(19961005)

32. Shoener, B.D., Schramm, S.M., Béline, F., Bernard, O., Martínez, C., Plósz, B.G., Snowling, S., Steyer, J.P., Valverde-Pérez, B., Wágner, D., Guest, J.S., 2019. Microalgae and cyanobacteria modeling in water resource recovery facilities: A critical review. Water Res. X 2, 100024. https://doi.org/10.1016/j.wroa.2018.100024

33. Vergara, C., Muñoz, R., Campos, J. L., Seeger, M., Jeison, D., 2016. Influence of light intensity on bacterial nitrifying activity in algal-bacterial photobioreactors and its implications for microalgae-based wastewater treatment. Int. Biodeterior. Biodegrad. 114, 116-121. http://dx.doi.org/10.1016/j.ibiod.2016.06.006 
34. Whitton, R., Le Mével, A., Pidou, M., Ometto, F., Villa, R., Jefferson, B., 2016. Influence of microalgal $\mathrm{N}$ and $\mathrm{P}$ composition on wastewater nutrient $\begin{array}{llll}\text { remediation. } & \text { Water } & \text { Res. } & \text { 371-378. }\end{array}$ https://doi.org/10.1016/j.watres.2015.12.054

35. Winkler, M.K.H., Straka, L., 2019. New directions in biological nitrogen removal and recovery from wastewater. Current Opinion in Biotechnology 57C, 50-55. https://doi.org/10.1016/j.copbio.2018.12.007

36. Yang, S., Wang, J., Cong, W., Cai, Z., Ouyang, F. 2004. Utilization of nitrite as a nitrogen source by Botryococcus braunii. Biotechnol. Lett. 26(3), 239-243. https://doi.org/10.1023/B:BILE.0000013722.45527.18 